\title{
Community local wisdom of Kasepuhan community at Mount Halimun in conserving natural resources and environment
}

\author{
Henly Yulina $^{1 *}$, M. Ade M. Kramadibrata ${ }^{2}$, N. D. Airinda ${ }^{3}$ \\ ${ }^{1}$ Lecturer, Faculty of Agriculture, Wiralodra University, Indramayu, Indonesia \\ ${ }^{2}$ Directorate of Research and Community Service University of Padjadjaran, Padjadjaran University, Indonesia \\ ${ }^{3}$ Indonesian Research Center for Indigenous Knowledge (INRIK) \\ *Corresponding author: henlyyulina2089@gmail.com
}

\section{ABSTRACT}

Indigenous system (as a form of traditional wisdom for generations proven effective in maintaining and ensuring the sustainability of public life of Kasepuhan Community at Mount Halimun) needs to be adopted and synergized in regional development related to conservation of natural resources and the environment. Research with non-experimental method of explorative surveys conducted to describe the perceptions and cultural communities to their natural environment. The results showed that the perception of the community rooted in a division system of forest functions and traditional agricultural systems - especially in rice systems like rice or paddy fields, two systems are still adhered to today, where traditional agriculture that are adaptive to the local environment turns out to be a sort of "germplasm bank" of local rice varieties that became a source of food as well as life's basic principal that is forbidden to be traded. The systems thus, protect the existence of water resources to preserve the long-term agricultural systems, community life, and the environment as a whole.

Keywords: Kasepuhan community at Mount Halimun, indigenous system, division system of forest functions, traditional farming systems, sustainability

\section{INTRODUCTION}

Wisdom or traditional knowledge is a concept or system of local knowledge held by traditional communities in an area (Mitchell, 1997). This knowledge system is a custom of hereditary have practical knowledge in order to survive in the natural environment.
Kasepuhan communities living around the Mist Mountain National Park, West Java, for example, are known to have practical knowledge to conserve natural a form of adaptation to the environment which is typical. Knowledge system, such as agriculture, fisheries, agriculture, and health, as well as how it will manage their environment. It is essential for their survival.

However, knowledge or traditional knowledge are often recessive and eliminated over time and the rapid process of development in the surrounding. This happens because the approach to development that occurs is generally done in "top -down", or departed from the views "outside the community" with a method which is considered more scientific and modern (Rambo, 1982).

Whereas traditional knowledge is considered less meet the demands of progress, such a case known as Green Revolution in agriculture development. In addition to the benefits of productivity increase, there is also a variety of failures, which include declining biodiversity, the dependence of farmers to sources outside the community, such as fertilizers and pesticides, as well as the prevalence of various pests. Development would be fairer if the community as a whole to be more involved actively, including traditional society.

Facts shown from some studies indicated that local knowledge is mainly related to the conservation of natural resources, biodiversity, and sustainable living environment proved to be very adaptable and may be superior to the scientific approach that comes from outside of the community.

Indonesia with cultural diversity and traditional customs, have various kinds of traditional wisdom. However, extracting, assessment, and documentation of scientifically remains piecemeal and less significant. 
Therefore, by examining traditional knowledge systems is expected to more in-depth practical knowledge that can be learned and reapplied in order to address environmental issues, biodiversity, and dependence over use of farmers to outsiders. In addition, if the traditional wisdom can be documented scientifically, then the efforts of piracy committed by foreign parties can be avoided.

This study will discuss the various forms of local knowledge related to the conservation of natural resources and the environment at Kesepuhan community and explain how the development process that comes from the outsides in contact with the local wisdom.

\section{METHOD}

Research used exploratory surveys (non-experimental) with variable and research instruments such aspects, variables, objectives, and instruments / ways of collecting data.

\section{RESULTS AND DISCUSSION}

\section{Farming Systems}

Agricultural systems by Kasepuhan community, primarily rice based to huma rice or paddy field farming which is a cultural heritage subsistence agriculture, which is now developing into rainfed. Swidden farming itself is often accused of being the source of damage to land and forest clearing, which is not necessarily so. Shifting cultivation follows the pattern of adaptive rules also with the environment. They are not the origin of clearing and thereafter abandoned, but will be reopened after a few years ( Soedjito, H. 1996).

\section{a. Dry Rice Cultivation}

Farming activities by opening the forest - called leuweng (forest) type, an ancient custom of Kesepuhan society heredity that is more akin to shifting cultivation outside Java. At first the practice was carried out in the forest area and forest production area of TNGH that is managed by Perum Perhutani. Thence, the forest management system is held by the state, there is a massive restrictions against the customary open fields. Currently farming as the Kesepuhan people do is among others not the only major way of farmings. Nevertheless traditional practices they carry out are still guided closely to the local pattern and farming cycle, as shown below;

\section{Table 1. Field Agriculture Cycle}

At the beginning of the opening of forests into fields, a pioneer requested permission to elders or village elders delight for those who live far from Kampung Gede to ask for the blessing symbolized in the form of incense and panglay (Zinglber cassumuar). If it has found the right place, he put up a sign in the form of stakes or ties leaf weeds in the vicinity. Before the site opened a simple ceremony performed by the person who called sasarap, whose meaning is a prayer to ask permission to the ancestors. After that just do nyacar activities that cut the stems and branches that will cover the rice growth, without cutting down a tree with a sickle and ax tool. Usually done in the months of Hajj and lasts 15 to 30 HRI depending on the area that opened (Nugraheni , E and A. Winata, 2002).

After that tenants do more small ceremony called prayer request permission ngabersihan/ nyaangan. After the branches and twigs are collected in the center of the area to be burned and the surrounding land is limited so that the fire would not spread. The combustion process is called ngahuru and the rest then burned again (ngaduruk). Usually these activities are carried on Month of Muharram . After the area is left for 10 days to grow grass. At the time it was done back in the so-called clean-up dredged or diparel. Five days later entered the crucial stage which ngaseuk which falls in Sapar.

Ngaseuk or grow rice in the fields is a fairly large ceremonial and festive, which involves all the traditional leaders and the entertainment arts such as reading rhymes, puppets, jipeng, mask, and others. In the morning began to dawn begins early rice planting done by indigenous leader and interpreter of farmers, then share work done by other people.

About 15 days after planting, the grass that grows is cleaned up (dikored or dioyos) . the second cleaning is called ngarambas. Then the fields are fertilized (diberak). Around the edges of the fields are also cleared -called dibalungbang, after the farmers wait to the time of harvest

After about three months, in Rewah start harvesting. Before the rice harvest (ditegel) performed the ceremony mipit or copy the usual also called. Both indigenous villages are each sending prayers to the ancestors of the 
night before. On the next day, his wife, accompanied by the Chairman of Indigenous shamans farmer with neat and clean clothes to go to the fields, doing a series of rites and spells, then began cutting rice in the fields. These events should not be seen by anyone. After Adat finished, and then people come to the field and start cutting rice.

Rice harvested are not immediately taken home, but dried in the field called ngalantay. Once dry, then tied up and kept in a certain place before it is put into the barn (leuit). Previously a simple ceremony is carried out, called ngadiukkeun. Before the rice is used there is another simple ceremony that is called nganyaran (initial use of newly harvested rice). Afterward ngazakat (zakat) is held where one-tenth of the harvest is to be given to those who can not afford any harvests. The last stage, rice is put in the largest collective barn (Leuit) accompanied by a ceremony that called Seren Taun (Nugraheni, E and A. Winata, 2002)

The first year after the harvest, the fields are called jami. Depending on soil conditions, then after harvesting, they can re-use that field or not. The local community decided to reuse their fields based on the amount of water that seep out of the ground. Then the field will be used to plant corn or beans for one or two more years. After that, there are two alternatives that can be done, let it be a forest that is returned or made into a garden and talun (fruit and/or wood trees planted land).

The fields are left will be the young shrubs (Rheumatic wondered) and then scrub the old (reuna stodgy), and then grow into secondary forest. After five years as a secondary forest, the new community considers the forest is quite " old " to be reopened into the fields

However, the practice of shifting cultivation are traditionally those at the moment is hardly done anymore with regard to restrictions relating to the national park. In agriculture it is graduallychanged to rice field constructing.

\section{b . Paddy Field}

Rice cultivation patterns among Kasepuhan residents is a new adjustment patterns, which many do when there were restrictions on new forest clearing for cultivation. Soil that is usually left fallow and abandoned succession to occur naturally become young and old shrubs, and secondary forest, become molded into a rain-fed rice, or irrigated paddy fields, if there is a stream nearby that can be utilized .

The standard time to cultivate the fields and carry out their traditional ceremonies are still based on the pattern of timing for agricultural fields. They are calculated in a such way that the time and the ceremony of seren taun can be done simultaneously for both the upland and wetland farmers. Harvest in various Kampoong kasepuhan is carried out at the same time. While the initial start stocking plant is set up in such a way according to weather conditions and seed types used, i.e., determined in $40,50,70$, or 80 days.

Starters plant and harvest specified in the usual ceremony ponggokan done a week ahead of the Seren Taun. In the ceremony ponggokan the things spoken by elders include stocking and harvest time in every village, as well as details and budgets for events seren epidemic. Complete cycle of rice cultivation are noted below:

\section{Table 2. Wetland Paddy Cycle}

Agricultural cycle begins with preparing the seeds, ie since the rice is still standing in the previous planting season. Selected results of the best rice that will be used as seed. Clumps of rice is then cut carefully by using planers (dietem), then chooses the best-select which one will be the seedlings. Clumps of rice then soaked overnight, then put into containers such as jars large (tambilung) by way of neatly organized, wait until it comes out the root / germination (akaran). After the cut straw clumps $5-10 \mathrm{~cm}$, and the seedlings are ready for planting (melak).

Meanwhile, in the place / plot seeding, rice fields dried (disaatan), improved rice field (mopok galeng), then turn down straw (ngabaladah), and then irrigated rice fields (ngambangkeun). The next stage is ngangler, i.e., flatten and soften the watery soil by using a plow, so that the soil is ready for planting seeds.

The seeds were then planted in a manner laid out in mud, then pressed with index finger (dilelepkeun) and one end bent so that most of the rice straw got out of the mud surface. After the water to hide hatchery opened (kokocoran mandible). Toward evening reduced water volume (disaatan), the next morning energized flow again so that the rice is resubmerged. How nurseries are referred to as stocking. Rice seedlings that have grown can then be pulled up to be planted 
While the activity is the same paddy processing is the same as the land management fatherly seeding, the paddy dibabad, hoeing, and then straw behind, then watered and plowed until ready for planting. Was planted rice seedlings in paddy fields at the right time, the so-called graft (laid while backward). After the paddy was 15 days then fertilization (ngaberak). In the past residents only memepergunakan kasepuhan busukan manure and leaves, but now they use anyway when urea and TSP.

The next maintenance step is to clean the grass that grows around the rice terraces (ngarambet), then clean the bund (chronicle galeng). After the rice is quite yellow then it is ready for harvest (mipit). Mipit ceremony similar to the rice fields. After harvest, the rice is dried in the fields (dilantay). Then the process is the same as the handling of paddy rice farm products, ie rice dipocong (tied about 3-4 kg), then collected (direongkeun) and stored in a place with ngadiukkeun ceremony. Then the new rice pulverized (ditutu) in cooking (nganyaran) with the ceremony anyway, then ngazakat activities, and then be ready for the biggest ceremony seren epidemic, which handed over some of the crops to be included in rice granary (leuit) (Nugraheni and Winata, 2002).

Rice varieties planted are local varieties that they collect and cultivated its own, which until now has reached 148 species. They choose the type of rice to be planted based on a match with the season and the height of land. Rice is planted once a year (not the type of seeds that can be harvested several times a year). Traditional rice varieties they planted in locations with a height of 900-1200 m include: Cinde, Angsana, Pondok Gajah, Gajah Bareuh, and Sunlig. As for the sticky rice is a type of Bogor, deer, and Beureum . For the rice fields at an altitude of $600 \mathrm{~m}$ they grow: Angsana, Cere Abah, Sri Yellow, Bull, and Pare Bandung. Non Kasepuhan communities who live in the same village with residents to plant rice free Kasepuhan superior type anything and anytime. However, many people of Non-Kasepuhan also followed the ways of indigenous anyway.

\section{c. Calendar of Agriculture}

Farm life plays a central role in society Kasepuhan. As already mentioned, various customs associated with the many important aspects of the farm. Various ceremonies held in conjunction with each process and upon opening the land, sowing the seeds, to harvesting.
To make the process of planting both in the fields and rice paddies, they have a benchmark time of the growing season which is calculated based on the guidelines of astronomy, aitu by the appearance of certain constellations or planets and the moon around the earth orbit. Among members of a social group Kasepuhan, Elders Girang aide who served as shaman farmers obliged to calculate the time that is appropriate for each stage in farming (Nugraheni, E and A. Winata, 2002).

Their agricultural calendar that is based on the velocity of the moon and the star position different from the $\mathrm{AD}$ calendar that we commonly use everyday based on the rotation of the earth to the sun.

\section{Table 3. Agriculture Calendar of Kasepuhan Community}

In addition to the calculation based on the position of the moon and the community Kasepuhan also know how to calculate good and bad days based forecast / mujarobat calculated from Neptu and day as in the Javanese calendar (Neptu is like kliwon, sweet, pahing, pounds, etc).

The rule of thumb is to farm fields / huma. After shifting agricultural patterns into paddy fields, the benchmark is still used with some adjustments. For now begin cultivating rice in paddy determined by calculating backwards from the benchmark time scary epidemic.

\section{CONCLUDING REMARK}

With the adoption of agricultural method of wetland paddy fields, indicating that the nature of culture and customs actually be dynamic, in the sense of willing to make changes within certain limits. However paddy farming method adopted is the traditional paddy farming where planting is only done once a year and not intensive paddy of green revolution products with a super variety of seeds, fertilizers and chemical pesticides.

Perceptions and attitudes are reflected in the customs rules relating to rice plant is their way of conserving nature. Because rice is considered a sacred plant (incarnation of Dewi Sri), then it is proper they treat rice with respect. Rice only learned by ani-ani (traditional rice cutting tools), and should not be with a sickle or machete. For high quality seeds of rice plant is not as high as the traditional rice, then harvesting using scyte 
will be less effective, and it will be easier when harvesting by sickle and in the management they only want to use a mortar and should not use any hullers in the plant.

The positive impact that occurs due to still in use of traditional rice varieties is the preservation of traditional rice varieties they own. Intentionally they maintain and even enrich the traditional manner rice varieties suitable for any place at different heights and in different seasons. to the time of the study, they have a collection of 148 varieties of local rice. So they have preserved the traditional palsma nuftah of rice, which in the environment outside their community may have become extinct displaced by rice quality seeds from the green revolution.

With the conservation of customs, the population remains Kasepuhan can coexist peacefully with the national park. Traditional wisdom they are adaptive and have been proven in a long period of time, was not in the opposite direction with the conservation policy which is the mission of Mount Halimun National Park.

\section{ACKNOWLEDGEMENT}

I would like to thank my guide, $\mathrm{M}$. Ade $\mathrm{M}$. Kramadibrata who has guide to finish this paper and $\mathrm{i}$

Table 1. Field Agriculture Cycle

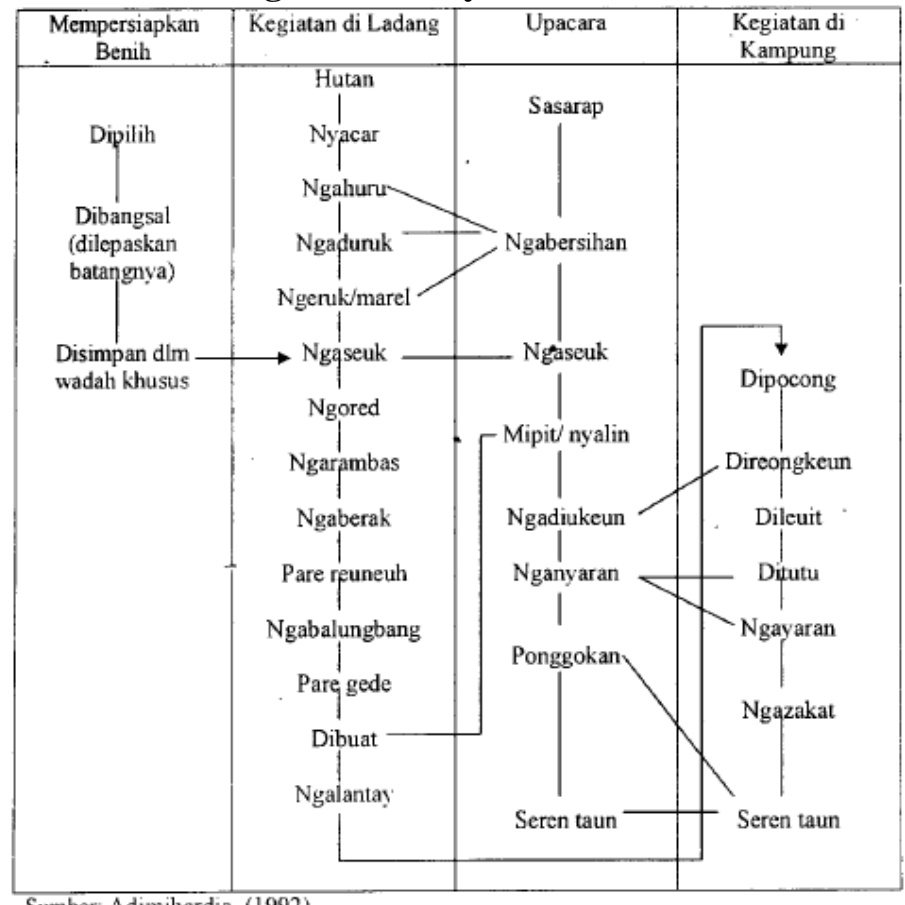

thank to Novida. D. Airinda who helped in the preparation and completion this paper.

\section{REFERENCE}

[1] Adimihardja, K. 1992. Kasepuhan yang Tumbuh di Atas yang Luruh, Pengelolaan Lingkungan Secara Tradisional di kawasan Gunung Halimun, Jawa Barat. Transito, Bandung.

[2] Mitchell, B. 1997. Resource and Environmental Management. Edisi Indonesia : Pengelolaan Sumberdaya Alam dan Lingkungan. 2002. Gadjah Mada University Press, Yogyakarta.

[3] Nugraheni, M dan A. Winata. 2002. Kearifan Tradisional Masyarakat Kasepuhan Halimun Ditinjau dari Aspek Kelestarian Lingkungan. Pusat Studi Indonesia. Lembaga Penelitian. Universitas Terbuka.

[4] Rambo, A.T. 1982. Human Ecologi Research on Tropical Agro-Ecosystem in South East Asia, Journal of Tropical Geography 3: 86-99.

[5] Soedjito, H. 1996. Masyarakat Dayak :peladang Berpindah dan Pelestari Plasma Nutfah, Kophalindo, Jakarta. 
Table 2. Wetland Paddy Cycle

\begin{tabular}{|c|c|c|c|c|}
\hline $\begin{array}{c}\text { Mempersiapk } \\
\text { an benih }\end{array}$ & Aktivitas di & Aktivitas di \\
pembenihan & sawah & Aktivitas di \\
kampung
\end{tabular}

Table 3. Agriculture Calendar of Kasepuhan Community 


\begin{tabular}{|c|c|c|c|c|}
\hline Simbol & Gejala Astronomi & Kegiatan pertanian & $\begin{array}{l}\text { Kalender } \\
\text { Islam }\end{array}$ & $\begin{array}{l}\text { Kalender } \\
\text { Masehi } \\
\text { 1999-2000 }\end{array}$ \\
\hline $\begin{array}{l}\text { a) Tanggal } \\
\text { Kerti kana } \\
\text { beusi tanggal } \\
\text { Kidang turun } \\
\text { Kujang }\end{array}$ & $\begin{array}{l}\text { Bintang Kerti atau } \\
\text { Bintang Tujuh mulai } \\
\text { muncul di ufuk barat. } \\
\text { Saat Bintang Kidang/ } \\
\text { Waluku/ Orion } \\
\text { muncul di ufuk timur }\end{array}$ & $\begin{array}{l}\text { Mempersiapkan alat } \\
\text { untuk bertani, misalnya } \\
\text { mempertajam kujang } \\
\text { (seperti sabit). } \\
\text { Petani siap mencacar } \\
\text { hutan untuk ladang }\end{array}$ & $\begin{array}{l}\text { Bulan } \\
\text { Haji } \\
\text { Dzul } \\
\text { Hijah }\end{array}$ & Maret \\
\hline $\begin{array}{l}\text { b) Kidang } \\
\text { ngarangsang } t i \\
\text { wetan, Kerti } \\
\text { ngarangsang } t i \\
\text { kulon atau } \\
\text { Kidang-kerti } \\
\text { pahareup- } \\
\text { hareup } \\
\end{array}$ & $\begin{array}{l}\text { Bintang Kidang } \\
\text { merembang dari arah } \\
\text { timur dan bintang } \\
\text { kerti dari arah barat, } \\
\text { sehingga posisi } \\
\text { kedua bintang } \\
\text { berhadapan }\end{array}$ & $\begin{array}{l}\text { Tanda musim kemarau } \\
\text { panjang, tanda saatnya } \\
\text { membakar ranting dan } \\
\text { daun (ngahuru) }\end{array}$ & $\begin{array}{l}\text { Bulan } \\
\text { Muharam }\end{array}$ & April \\
\hline $\begin{array}{l}\text { c) Kerti mudun. } \\
\text { Kidang matang } \\
\text { mencrang di } \\
\text { tengah langit }\end{array}$ & $\begin{array}{l}\text { Kedua bintang } \\
\text { menjadi sangat } \\
\text { terang }\end{array}$ & $\begin{array}{l}\text { Saat mulai menanam } \\
\text { padi (ngaseuk) tiba }\end{array}$ & $\begin{array}{l}\text { Bulan } \\
\text { Muharam } \\
\text { / Syafar }\end{array}$ & Mei \\
\hline $\begin{array}{l}\text { d) Kidang } \\
\text { medang turun } \\
\text { kungkang }\end{array}$ & $\begin{array}{l}\text { Kalau kedua bintang } \\
\text { mulai surut, hilang } \\
\text { dari pandangan kita. }\end{array}$ & $\begin{array}{l}\text { Saatnya datang hama } \\
\text { walang sangit } \\
\text { (kungkang) }\end{array}$ & $\begin{array}{l}\text { Bulan } \\
\text { Rajab/ } \\
\text { Syaban } \\
\end{array}$ & $\begin{array}{l}\text { Oktober/ } \\
\text { Nopember }\end{array}$ \\
\hline $\begin{array}{l}\text { e) Kidang Kerti } \\
\text { ka kulon }\end{array}$ & $\begin{array}{l}\text { Kedua bintang } \\
\text { bergerak ke arah } \\
\text { barat }\end{array}$ & $\begin{array}{l}\text { Tanda datangnya } \\
\text { musim hujan }\end{array}$ & $\begin{array}{l}\text { Bulan } \\
\text { Hapit/ } \\
\text { Rayagung }\end{array}$ & $\begin{array}{l}\text { Februari/ } \\
\text { Maret }\end{array}$ \\
\hline
\end{tabular}

